\title{
INFLUENCE ANALYSIS OF EXTRATROPICAL CYCLONES IN INCREASE OF SALINITY AT THE ESTUARY OF PATOS LAGOON, SOUTHERN BRAZIL
}

\author{
NATALIA PEREIRA, JEANE RODRIGUES, ANDREA DE LIMA RIBEIRO E FERNANDO D'INCAO \\ Universidade Federal do Rio Grande - Instituto de Oceanografia, Laboratório de Crustáceos Decápodos, Rio Grande - RS - Brasil. CEP \\ 96201-900 - natalialtp@gmail.com
}

\begin{abstract}
The extratropical cyclones are associates to frontals systems and air temperatures gradients at troposphere. The aim of this work was relate the effect of these cyclones in increase of salinity in the stream of access to Patos Lagoon. A climatologic analysis of extratropical cyclones that moved for northeast/east near to the coast of Rio Grande do Sul State, in two distinct periods: May 2006 to march 2007 and May 2007 to March 2008. The first one corresponds to an El Niño period and the second one to a La Niña period. This analysis was made through the satellite GOES-E images and for the surface synoptic maps available by CPTEC. The salinity data had been collected daily in the stream. The cyclogenesis during La Niña was bigger than EI Niño, however in El Niño period they had been more representative in the climatic change in the region, mainly in increase of the south wind intensity, that pushes saline water for inside of the estuary, so had more than increase in the salinity caused by the south wind during this period. However exists, the significant relationship between the extratropical cyclones of and the increase of salinity in the estuary of Patos Lagoon.
\end{abstract}

KEYWORDS: Extratropical cyclones, El Niño, La Niña, estuary, Patos Lagoon, salinity.

\section{RESUMO}

Análise climatológica dos ciclones extratropicais e sua influência no aumento da salinidade no estuário de Lagoa dos Patos, extremo sul do Brasil.

Os ciclones extratropicais estão associados à sistemas frontais e gradientes de temperatura do ar na troposfera. $\mathrm{O}$ objetivo foi relacionar o efeito dos ciclones extratropicais no aumento da salinidade no canal de acesso à lagoa. Foi feita uma análise dos ciclones extratropicais que se movem na direção nordeste / leste, ao longo da costa do Rio Grande do Sul, em dois períodos distintos: Maio de 2006-Março de 2007 e maio de 2007 a março de 2008. O primeiro corresponde a um período de El Niño e o segundo de La Niña. Esta análise foi realizada com as imagens do satélite GOES-E e com mapas sinóticos de superfície fornecidos pelo CPTEC. Os dados de salinidade foram coletados diariamente no canal. Os ciclones extratropicais ocorreram, em maior número, durante a La Niña, mas durante El Niño foram dominantes na mudança do clima na região, principalmente no aumento da intensidade do vento sul, o que empurra a água salgada para o estuário. Portanto, existe uma relação significativa entre a passagem de ciclones extratropicais no Atlântico Sul e o aumento da salinidade no estuário da Lagoa dos Patos.

PALAVRAS CHAVE: Ciclones extratropicais, El Niño, La Niña, estuario, Lagoa dos Patos, salinidade.

\section{INTRODUCTION}

The Patos Lagoon $\left(32^{\circ} \mathrm{S}, 40^{\circ} \mathrm{W}\right)$, located in the extreme south of Brazil, has a total area of 10,360 $\mathrm{km}^{2}$, being the world's largest choked lagoon (Kjerfve, 1986). In its southern portion presents an estuarine region of high productivity that is in constant communication with the sea. The penetration of ocean waters in this area influences directly the local salinity and promotes the entrance of marine species that depends on this environment to complete its development (Castello 1985, Asmus 1997).

The mouth of the lagoon is a region extremely susceptible to salinity changes, which occur due to an imbalance between the output of the freshwater pond and salt water intrusion from the ocean. Since the astronomical tide does not have significant influence on this lagoon (Kjerfve, 1986), changes in salinity occur due to meteorological phenomena such as rainfall and incidence of winds from the South quadrant (Herz, 1977; Möller, 1978; Calliari, 1980; Costa et al., 1978d).
In the studied area, the south wind is a consequence of the passage of frontal systems, which are associated with extratropical cyclones (Calliari et al 1998). The extratropical cyclones (or mid-latitude cyclones) are generated between the latitudes of $30^{\circ}$ and $60^{\circ}$ and are low atmospheric pressure systems at synoptic scale, having cold cores and always associated to frontal systems. Their trajectories follow the global flow of fluids, always moving from west to east. In satellite images these systems can be identified by clouds in a "comma" shape in the Northern Hemisphere and "inverted comma" in the Southern Hemisphere (Vianello \& Alves 1991) (Figure 1). The main consequence of extratropical cyclones for Southern Brazil occurs on the coast, with winds from south quadrant over $60 \mathrm{~km} / \mathrm{h}$ which cause high waves and extreme tidal events (Parise et al 2009). 


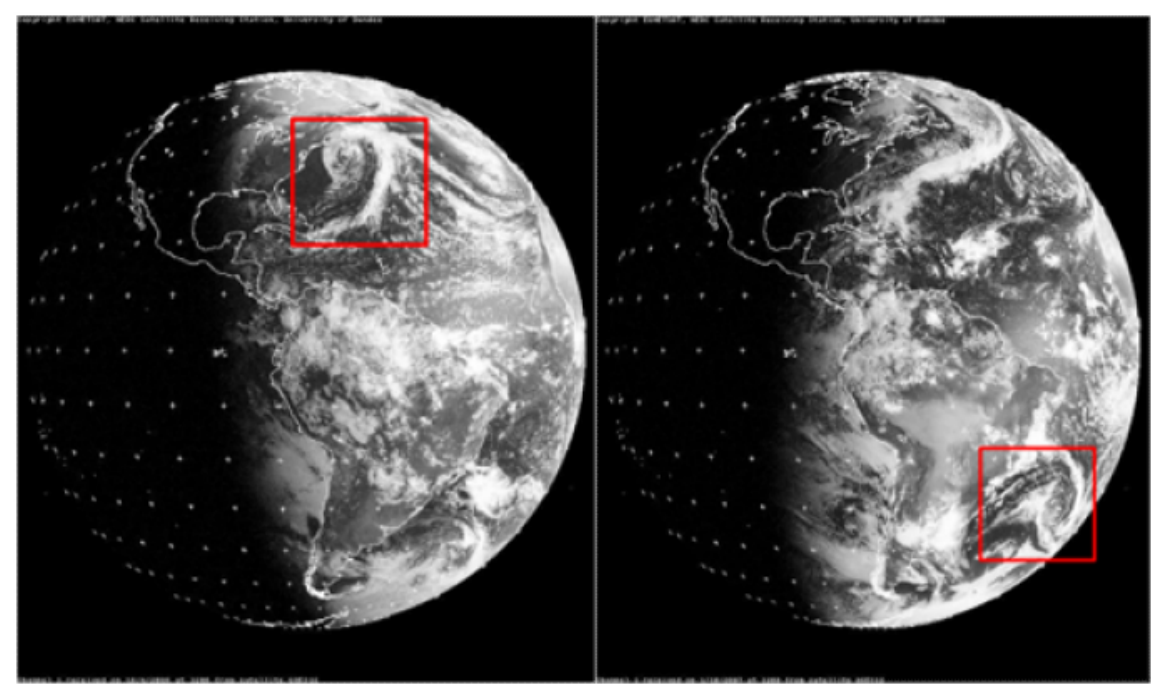

FIGURE 1 - Extratropical cyclone in the North Hemisphere and the Southern Hemisphere (Images from satellite GOES, IR spectrum)

In South America, two cyclogenetic regions were identified close to the shore, being one over Argentina (related to the baroclinic instability of the westerly wind) and another over Uruguay (around $31.5^{\circ} \mathrm{S}$ and $55^{\circ} \mathrm{W}$ ) associated with baroclinic instability due to the presence of the Andes (Gan \& Rao, 1991; Sinclair, 1994; Solman \& Menendez 2002). These cyclones exhibit a typical propagation throughout South America, from southwest to northeast (Lemos \& Calbete 1996)

Simmonds \& Keay (2000) indicates that in a period of six hours, there are about thirty-seven tropical cyclones in the Southern Hemisphere. Of these, on average, three reach the coast of Rio Grande do Sul (Gan \& Rao 1991).

Most of the meteorological studies for large data periods relied on data reanalysis of NCEP (National Center for Environmental Prediction) (Pezza
2003) and not particularly focused on the influence of ENSO phenomena in cyclogenesis. Thus, there is a necessity of developing studies that distinguish the behavior of extratropicals cyclones during periods of El Niño and La Niña. This diagnostic study aims to examine a single period of an El Niño and La Niña using data obtained by the analysis of surface synoptic charts and satellite images in order to obtain a more accurate essay.

\section{METHODOLOGY}

The region of interest in this study is situated on the South Atlantic Ocean between latitudes $25^{\circ} \mathrm{S}$ and $60^{\circ} \mathrm{S}$ and longitudes $70^{\circ} \mathrm{W}$ and $25^{\circ} \mathrm{W}$ (Fig. 2). 


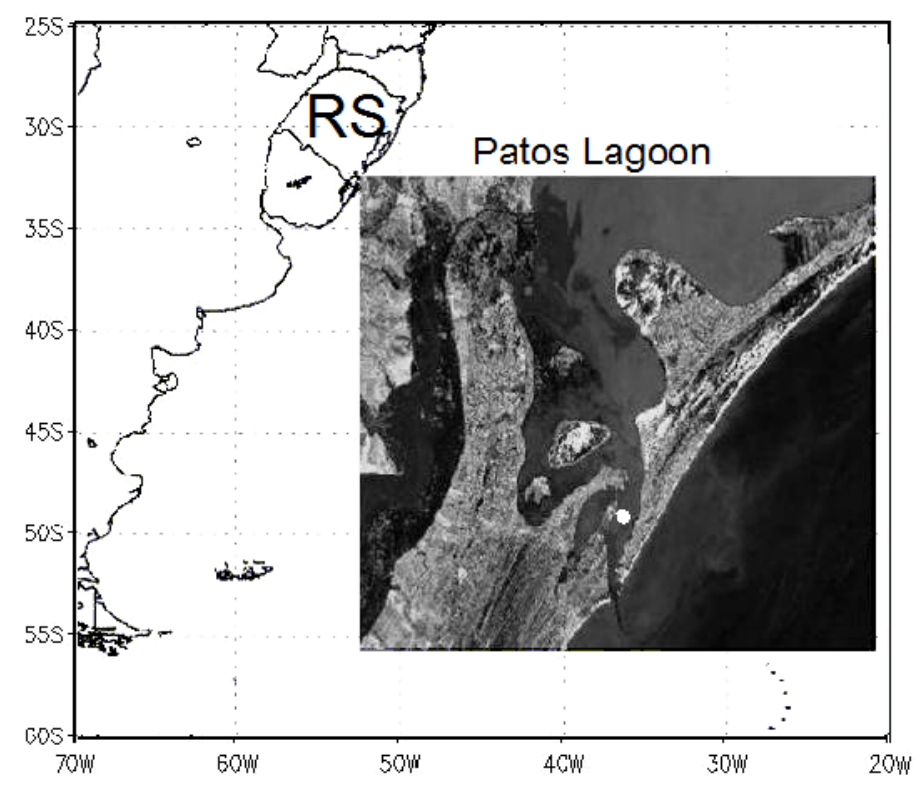

FIGURE 2 - Study area; in detail the Patos Lagoon estuary. The white point indicates the place of collection of salinity.

The analyzed period was from May 2006 to March 2008, as it encompasses an occurrence of El Niño followed by a La Niña. On total, 55 tropical cyclones were studied during de El Niño event and 67 during the La Niña period.

The intensity of the ENSO phenomena was taken from the website of NOAA (National Oceanographic and Atmospheric Administration).

In order to determine the location of tropical cyclones, GOES infrared satellite images of these hours were used: 0:00z, 12:00z e 18:00z UTC for each Day of the month. The atmospheric pressure of the core of cyclones was drawn from the surface synoptic charts, daily provided by CPTEC-INPE (Technology Research Center - National Institute of Space Research). These provide a synthesis of weather conditions of a given area aggregating isobars, contour and centers of high and low pressure in a single image. From the pressure information provided by the synoptic analysis, only cyclones with internal air pressure lower than $1010 \mathrm{hPa}$ were considered on this study.

The trajectories of the cyclones were determined with the assistance of numerical modeling software. At this stage, were entered data of geographical position in each of the times $(00: 00 z$, $12: 00 z$ and $18: 00 z$ UTC). After the data plotting, the cyclones trajectories were grouped seasonally. The stations are: Winter 2006, Spring 2006, Summer
2006/2007 (EL NIÑO); Winter 2007, Spring 2007, Summer 2007/2008 (LA NIÑA). The period of autumn 2007 was not analyzed because it referred to the months of neutral sea surface temperature.

The Laboratory of Decapod Crustaceans of the Federal University of Rio Grande collects samples of surface water daily since February 2005. Salinity is sampled at five different points of the Patos Lagoon estuary, maintaining a control of these annual variations.

In this work were used data of the point of salinity sample called Barra, located on channel between the estuary and ocean (indicated by a white dot in Figure 2), the first place where salinity variations occurs, which were compared with the passage of tropical cyclones.

Subsequently, the influence of tropical cyclones on salinity increase inside the estuary was determined by the calculation of percentages.

\section{RESULTS AND DISCUSSION}

According to the maps of trajectories (Figures 3 to 8 ) it is possible to identify differences in patterns of formation and trajectory of extratropicals cyclones (CE) during periods of EI Niño e La Ninã. 


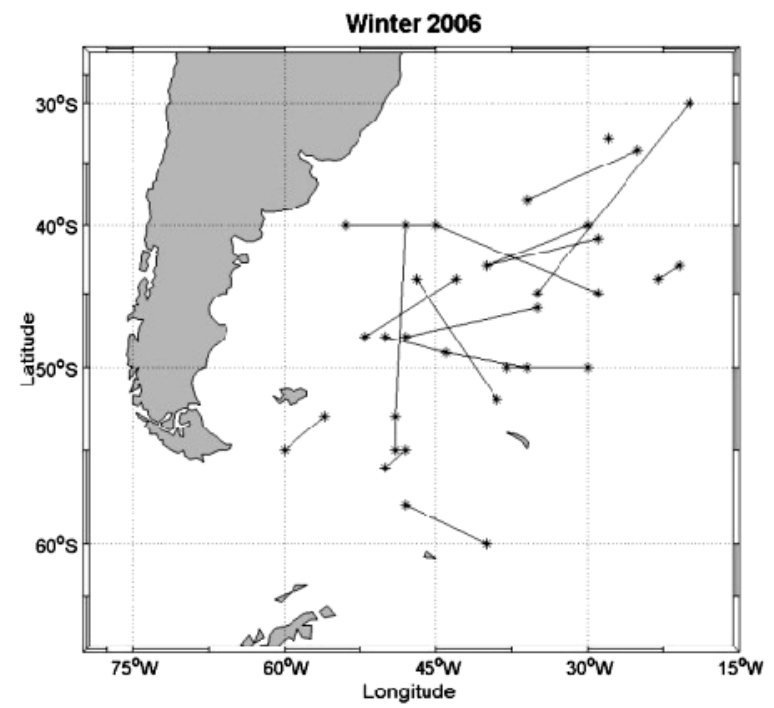

FIGURE 3 - Study area with the trajectory of 18 extratropicals cyclones analysed during the winter of 2006 (EI Niño).

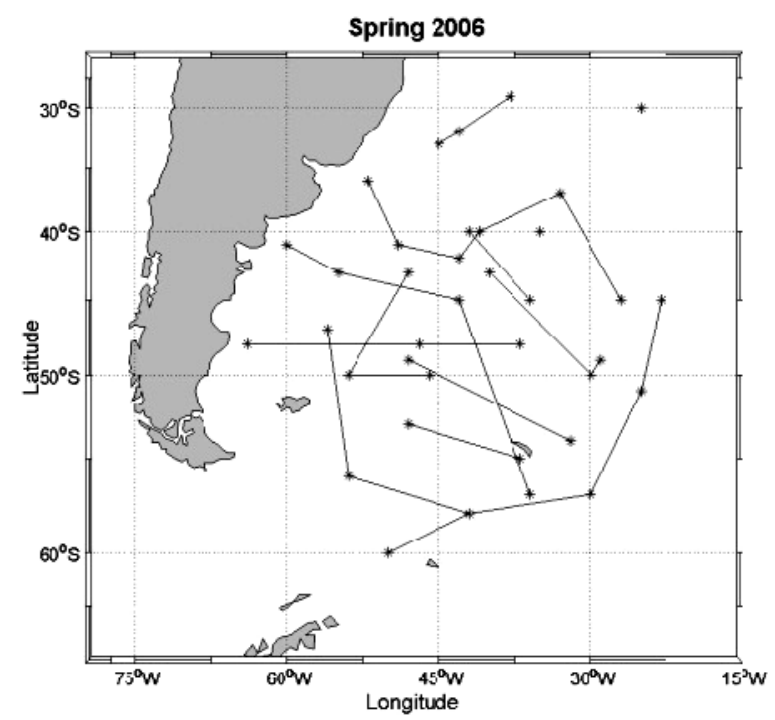

FIGURE 4 - Study area with the trajectory of 15 extratropicals cyclones analyzed during the spring of 2006 (EI Niño).

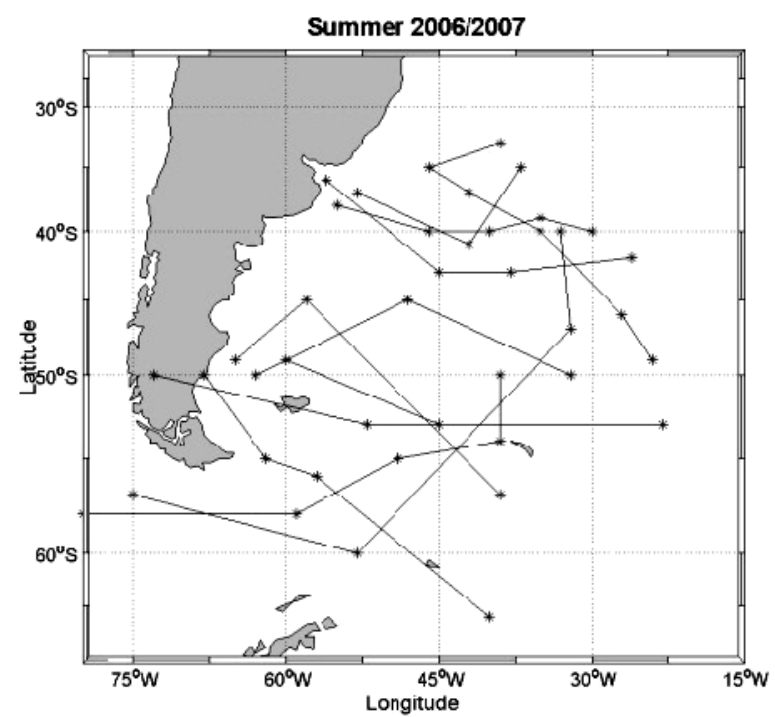

FIGURE 5 - Study area with the trajectory of 11 extratropicals cyclones analyzed during the summer of 2006/2007 (EI Niño). 


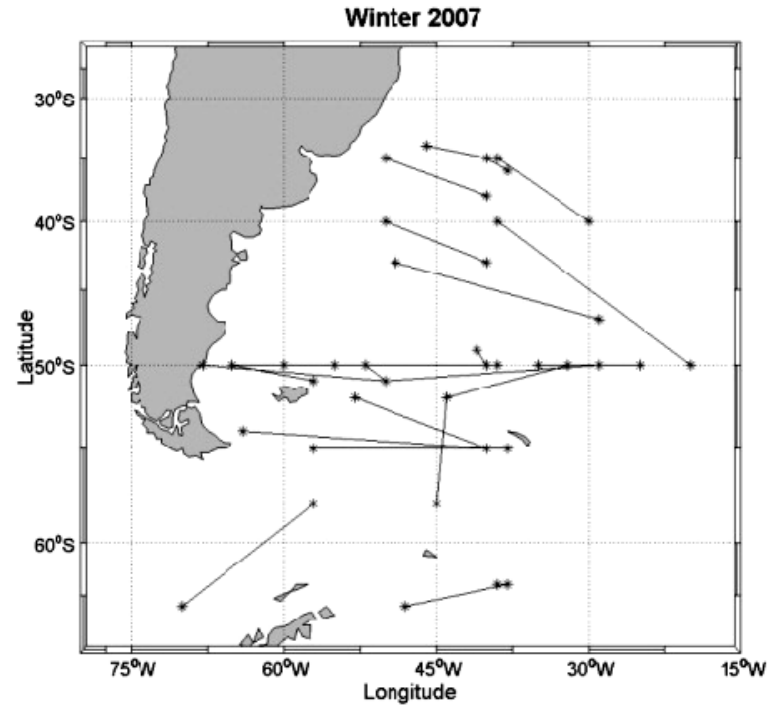

FIGURE 6 - Study area with the trajectory of 19 extratopicals cyclones analysed during the winter of 2007 (La Niña).

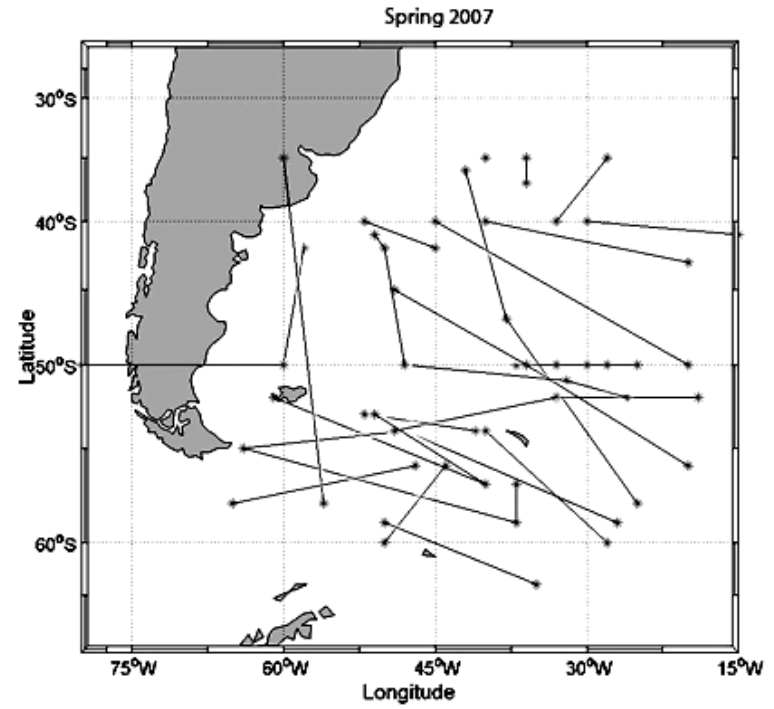

FIGURE 7 - Study area with the trajectory of 25 extrtatopicals cyclones analized during the spring of 2007 (La Niña).

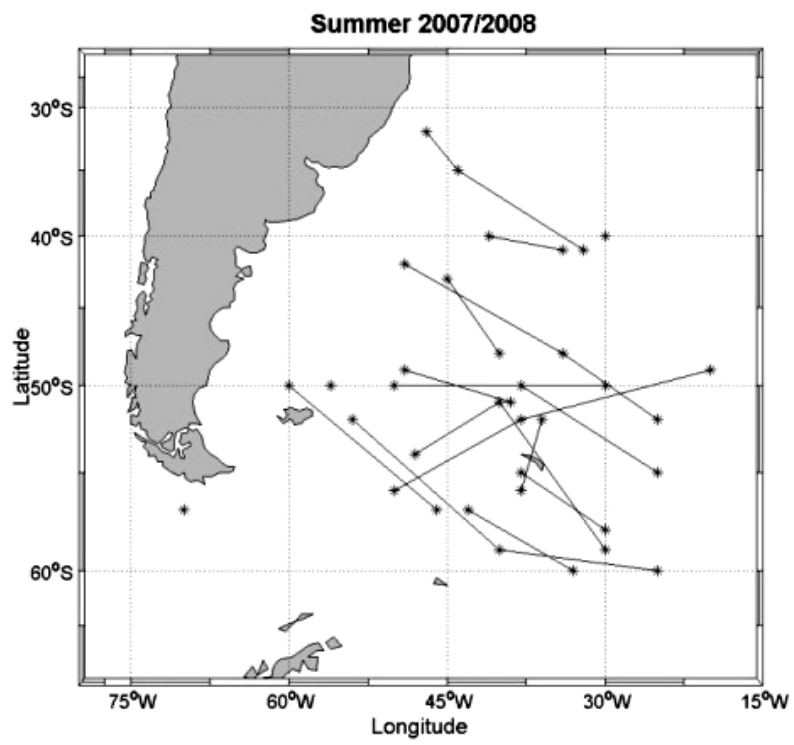

FIGURE 8 - Study area with the trajectory of 16 extratropicals cyclones analysed during the summer of 2007/2008 (La Niña). 
It was observed that in the months of El Niño the cyclogenesis occurs closer to the South America coast, while in La Niña months they occur further away towards toward the Atlantic ocean.

Were found three patterns of occurrence of cyclogenesis regions: region I comprises the area below latitude $47.5 \mathrm{~S}$; the region II above latitude 42.5
$\mathrm{S}$; and region III, a small region between latitude 42 and $47 \mathrm{~S}$, which confirms the areas determined by Parise et al 2009. During La Niña, there was a higher occurrence of cyclones in the region I (Figure 9).

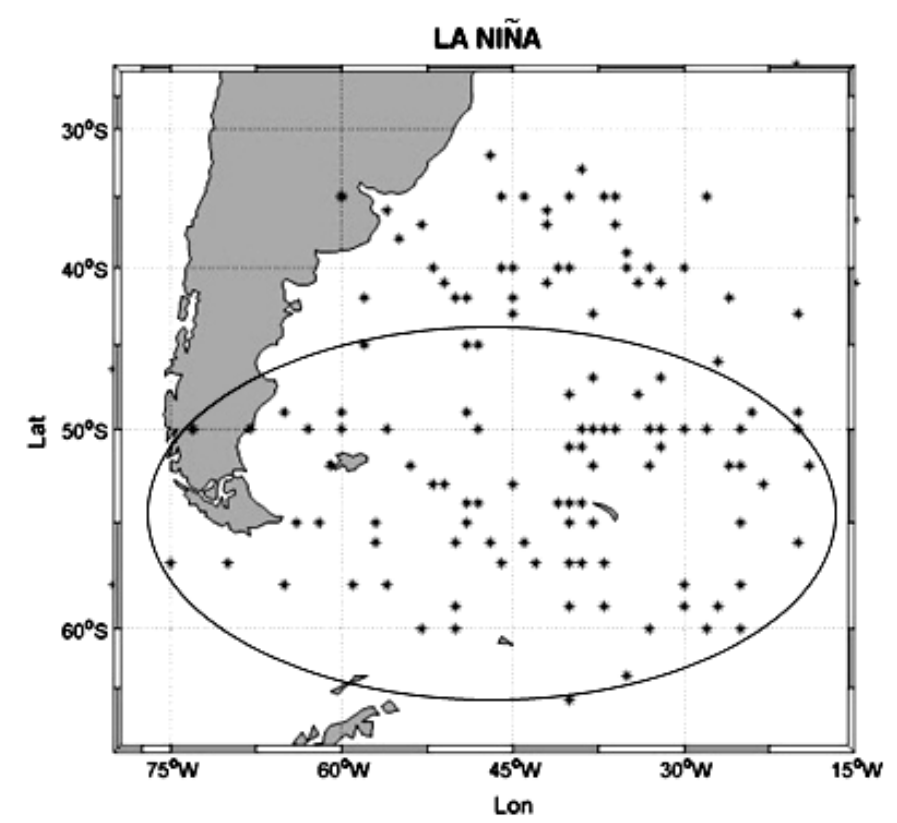

FIGURE 9 - Region of 67 cyclogenesis during La Niña (may 2007 to march 2008). The ellipse indicates a higher occurrence of extratropical cyclones below latitude $47.5 \mathrm{~S}$ (region I).

In contrast, during El Niño (figure 10), there $42.5^{\circ} \mathrm{S}$ (region II). were more occurrences of extratropical cyclones over

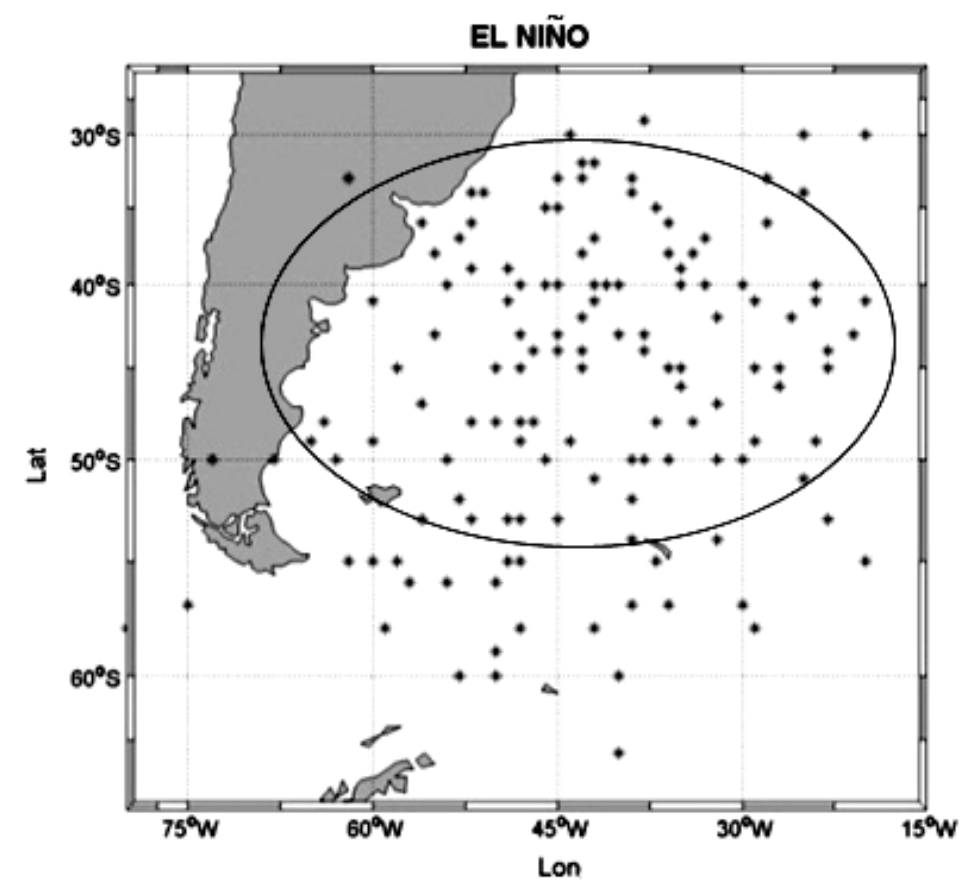

FIGURE 10 - Region of 55 cyclogenesis during EI Niño (may 2006 to march 2007). The ellipse indicates a higher occurrence of extratropical cyclones above latitude $42.5 \mathrm{~S}$ (region II). 
The number of cyclones in each of the periods analyzed (El Niño and La Niña) and its relationship with salinity increase in the Patos Lagoon is shown in Table 1.

\begin{tabular}{|c|c|c|c|c|c|c|c|}
\hline & $\mathrm{N}^{\circ}$ of cyclones & Days of occurrance & $\begin{array}{c}\text { Aver age duration of cyclones } \\
\text { (days) }\end{array}$ & $\%$ Increasing salinity & ZONE1 & ZONE2 & ZONE3 \\
\hline Winter 2006 & 18 & 36 & 2 & $63,50 \%$ & 6 & 5 & 7 \\
\hline Spring 2006 & 15 & 41 & 2,7 & $72,30 \%$ & 4 & 3 & 8 \\
\hline Summer 2007 & 11 & 42 & 3,8 & $94,30 \%$ & 5 & 3 & 4 \\
\hline Total EL NIÑO & 55 & 146 & 2,65 & $79 \%$ & 15 & 11 & 19 \\
\hline Winter 2007 & 19 & 44 & 2,3 & $36 \%$ & 12 & 4 & 2 \\
\hline Spring 2007 & 25 & 60 & 2,4 & $48,50 \%$ & 13 & 6 & 6 \\
\hline Summer 2008 & 16 & 37 & 2,3 & $80 \%$ & 12 & 3 & 2 \\
\hline Total LA NINA & 67 & 156 & 2.3 & $60 \%$ & 37 & 13 & 10 \\
\hline
\end{tabular}

The relationship between number of cyclones monthly by graphs (Figures 11 to 32 ). and salinity in the Patos Lagoon was also represented

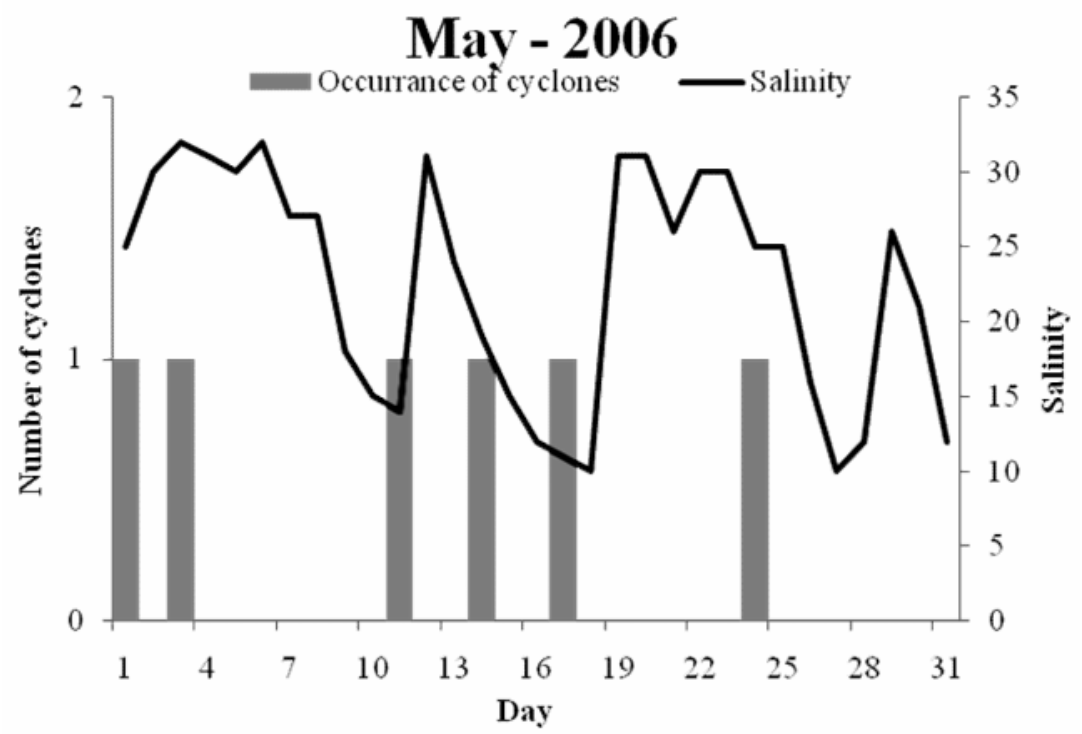

FIGURE 11 - Relationship between passage of extratropical cyclones and salinity in the estuary of Patos Lagoon in may/2006.

\section{June - 2006}

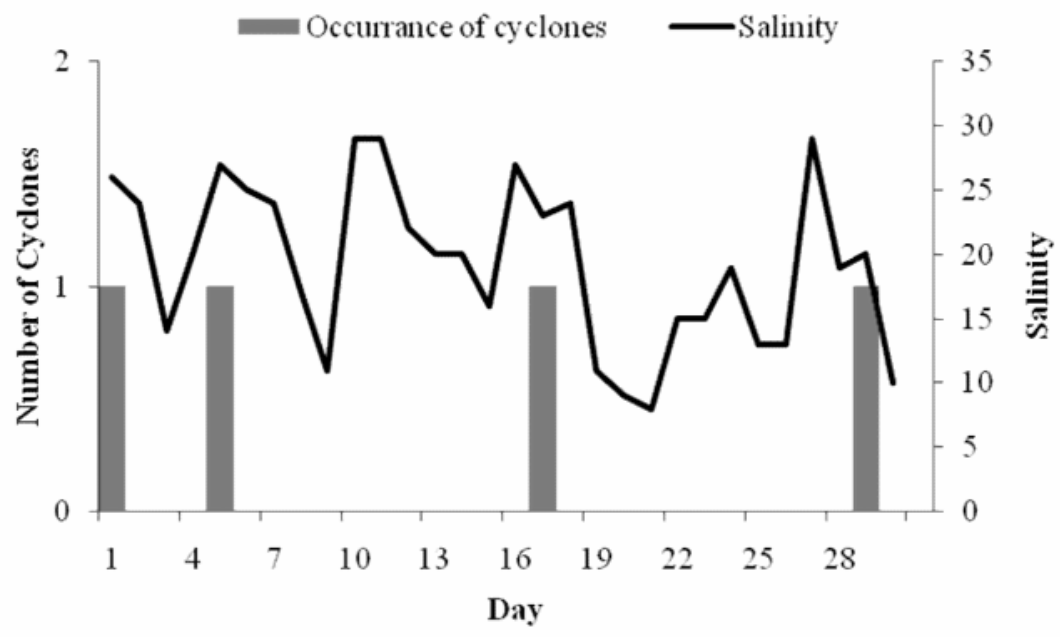

FIGURE 12 - Relationship between passage of extratropical cyclones and salinity in the estuary of Patos Lagoon in june/2006. 


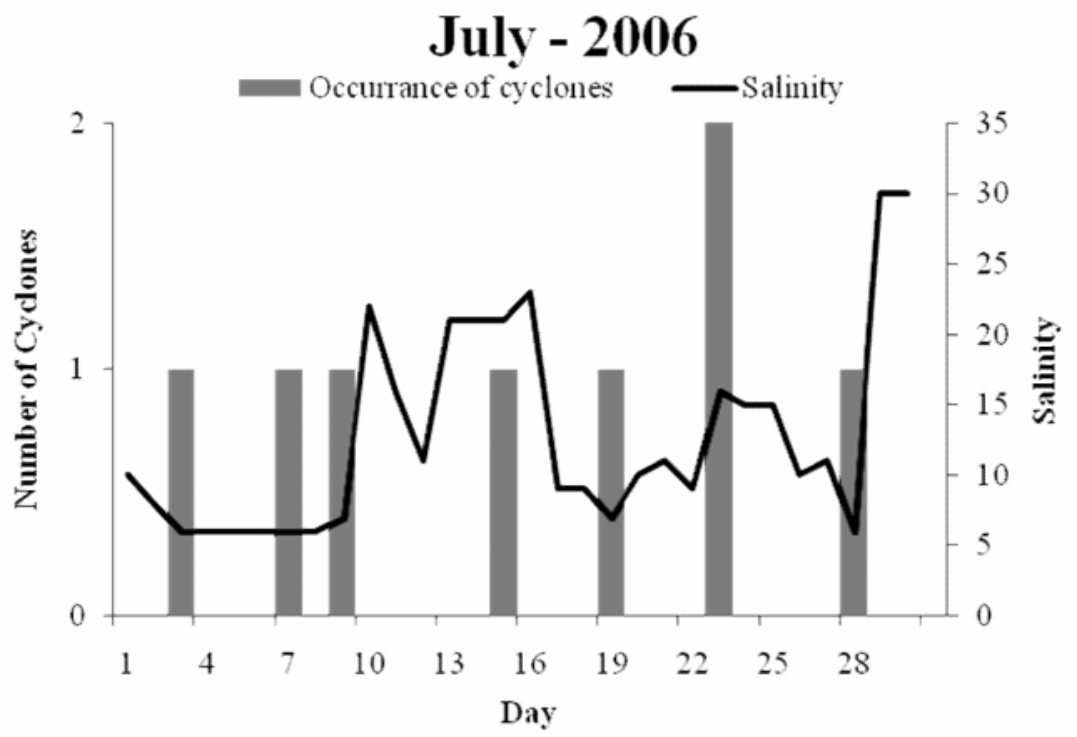

FIGURE 13 - Relationship between passage of extratropical cyclones and salinity in the estuary of Patos Lagoon in july/2006.

\section{August - 2006}

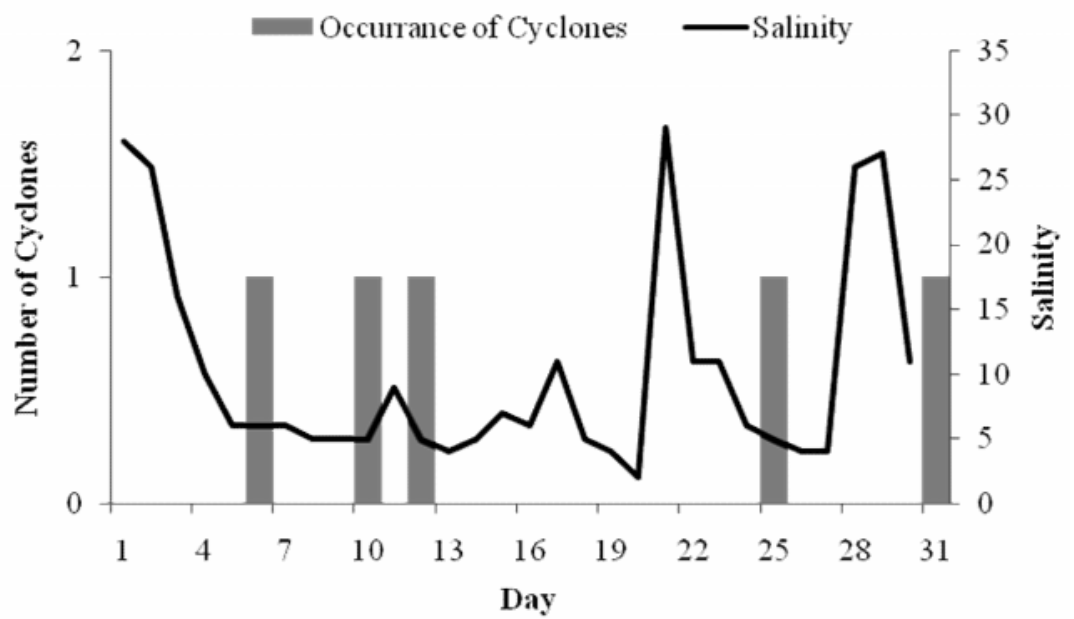

FIGURE 14 - Relationship between passage of extratropical cyclones and salinity in the estuary of Patos Lagoon in august/2006.

\section{September - 2006}

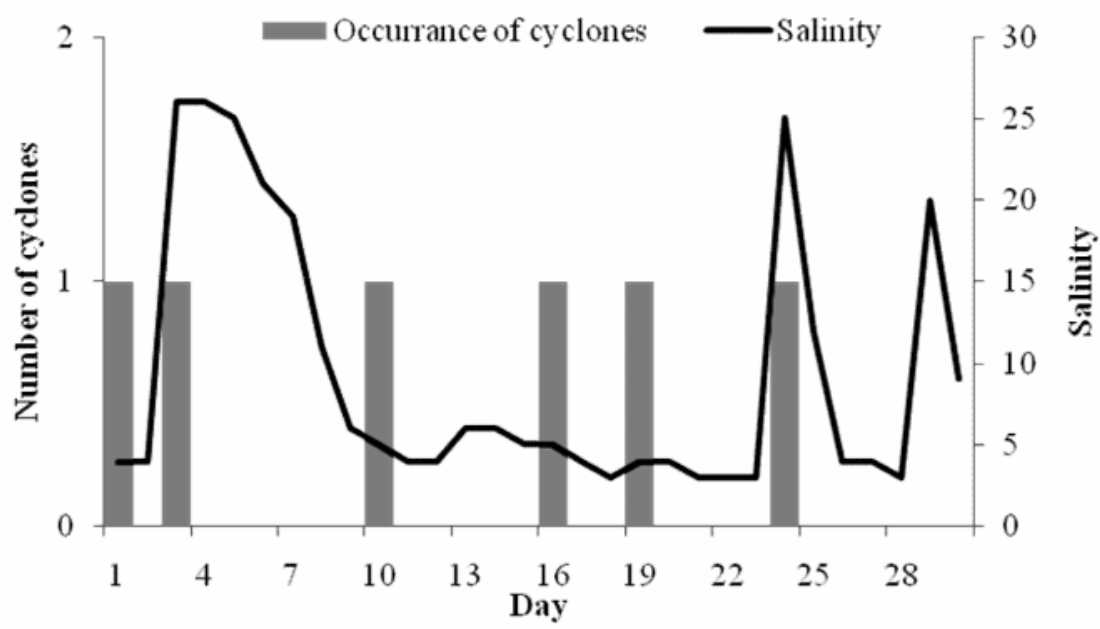

FIGURE 15 - Relationship between passage of extratropical cyclones and salinity in the estuary of Patos Lagoon in september/2006. 


\section{October - 2006}

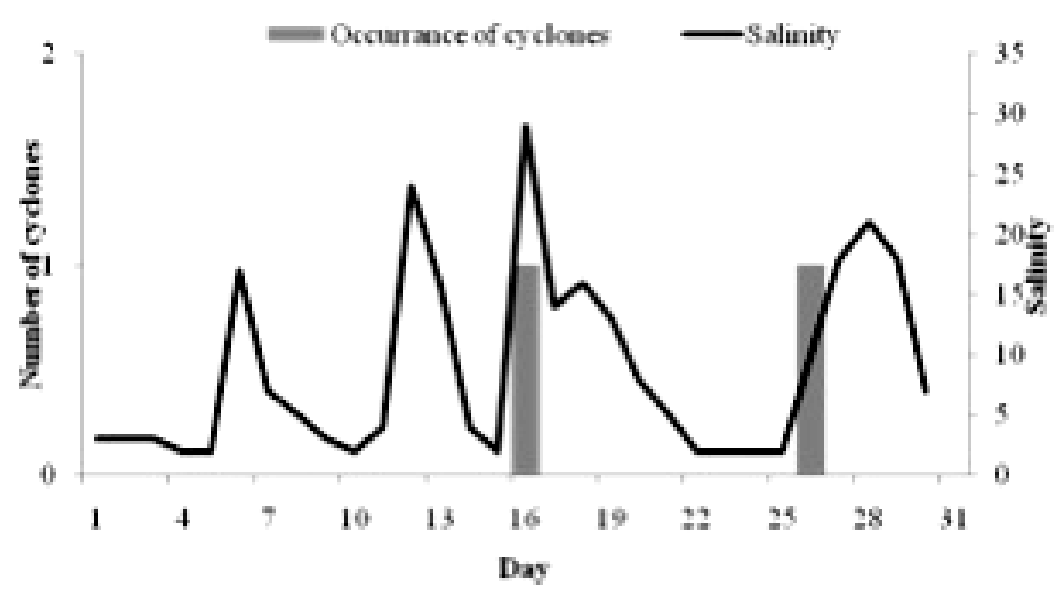

FIGURE 16 - Relationship between passage of extratropical cyclones and salinity in the estuary of Patos Lagoon in october/2006.

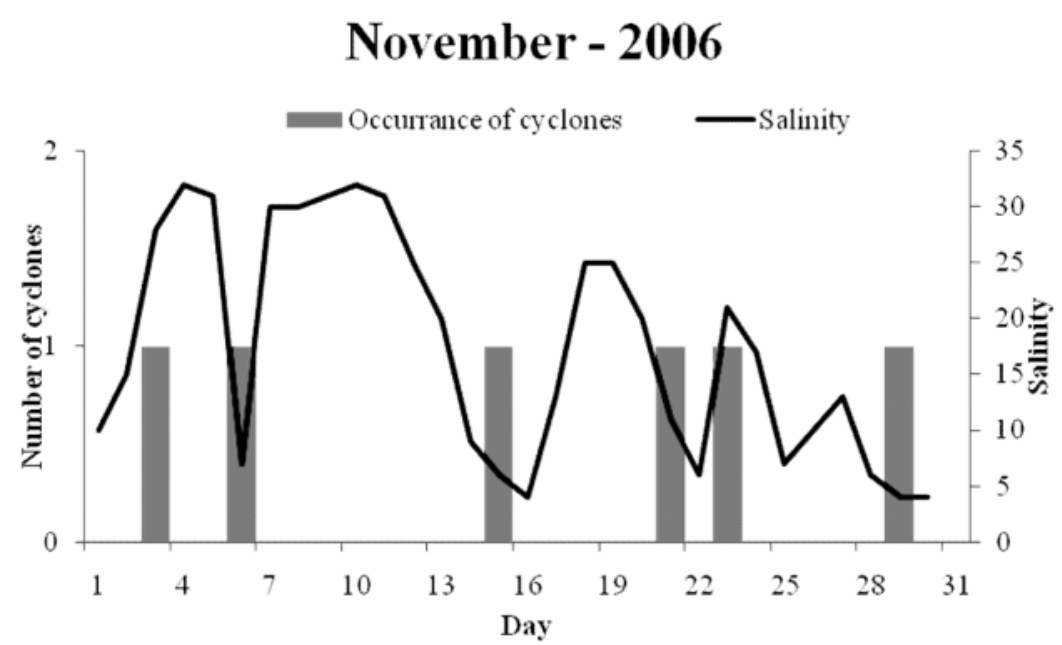

FIGURE 17 - Relationship between passage of extratropical cyclones and salinity in the estuary of Patos Lagoon in november/2006.

\section{December - 2006}

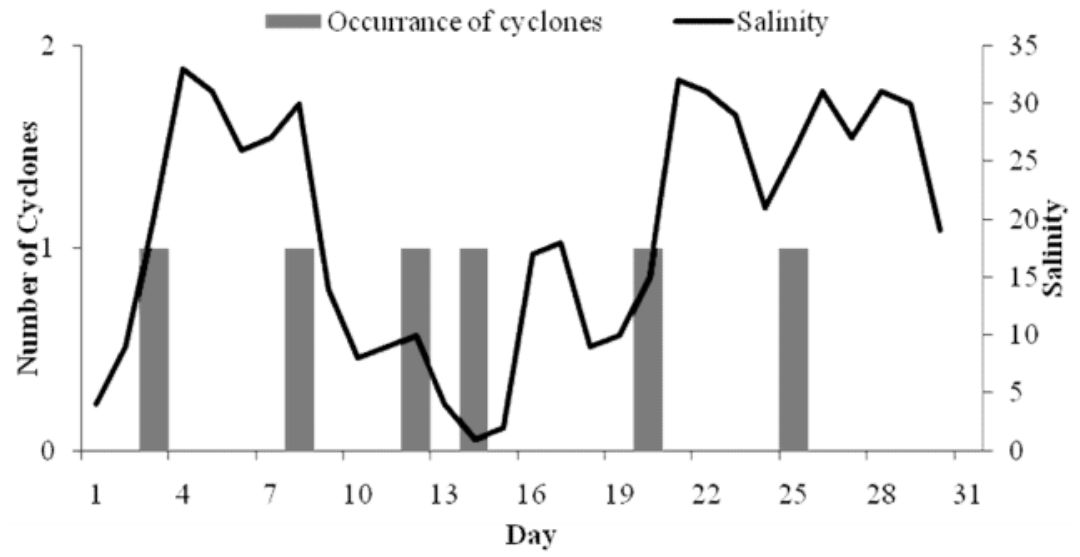

FIGURE 18 - Relationship between passage of extratropical cyclones and salinity in the estuary of Patos Lagoon in december/2006 


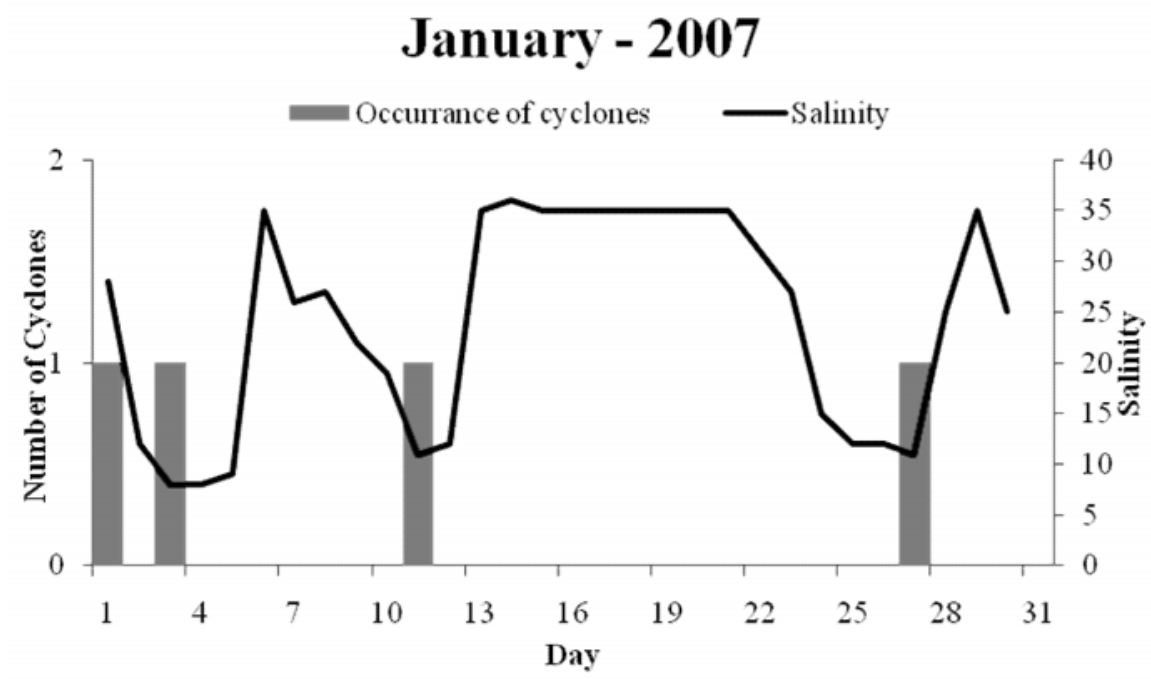

FIGURE 19 - Relationship between passage of extratropical cyclones and salinity in the estuary of Patos Lagoon in january/2007.

\section{February - 2007}

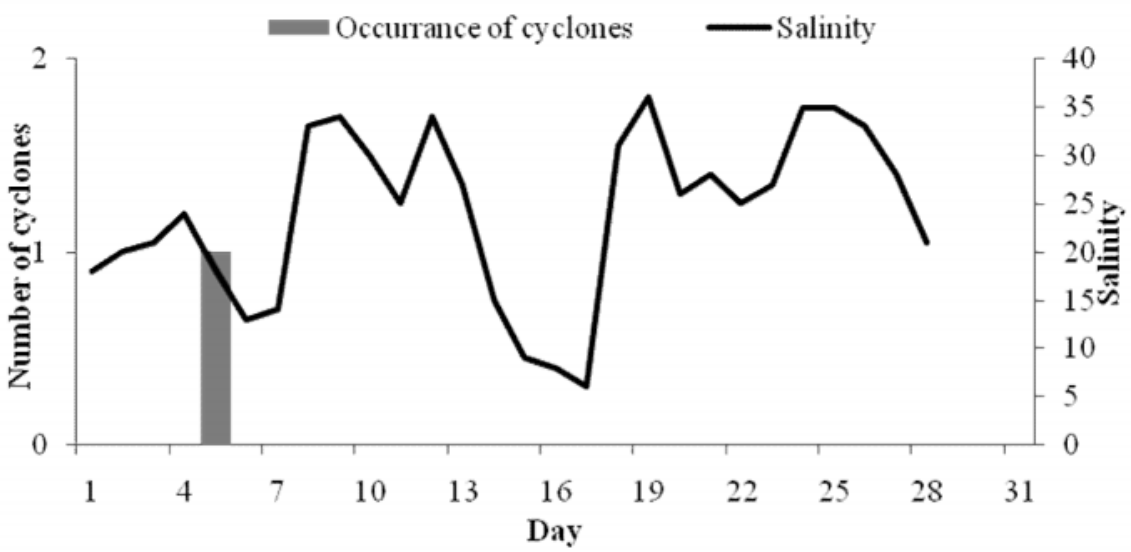

FIGURE 20 - Relationship between passage of extratropical cyclones and salinity in the estuary of Patos Lagoon in february/2007.

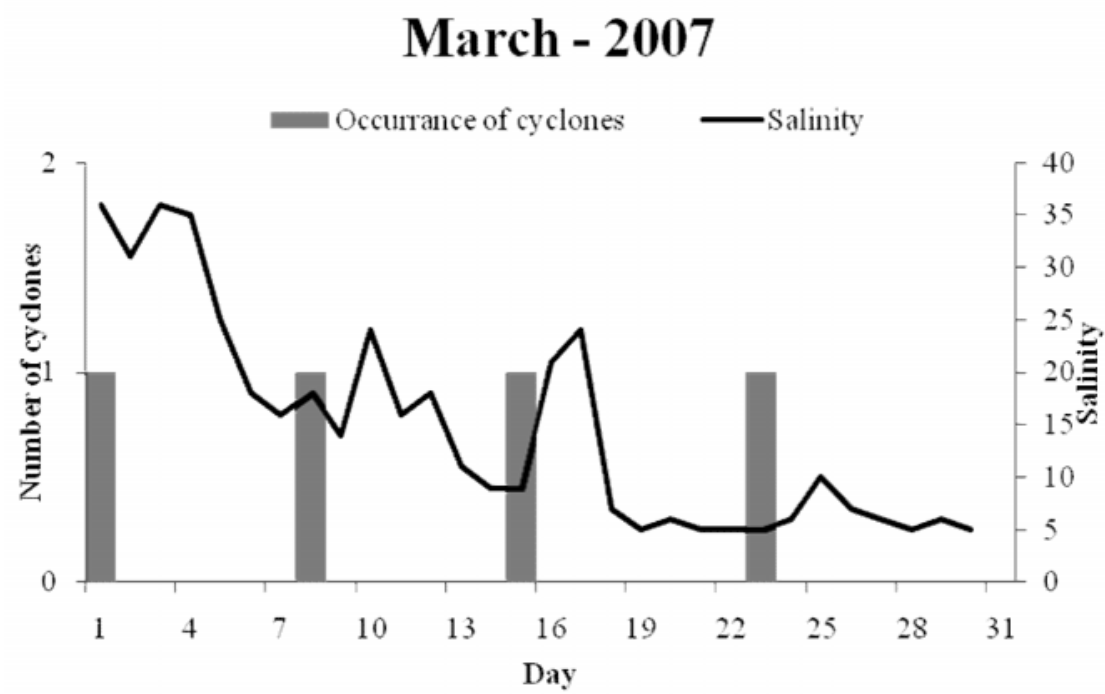

FIGURE 21 - Relationship between passage of extratropical cyclones and salinity in the estuary of Patos Lagoon in march/2007. 


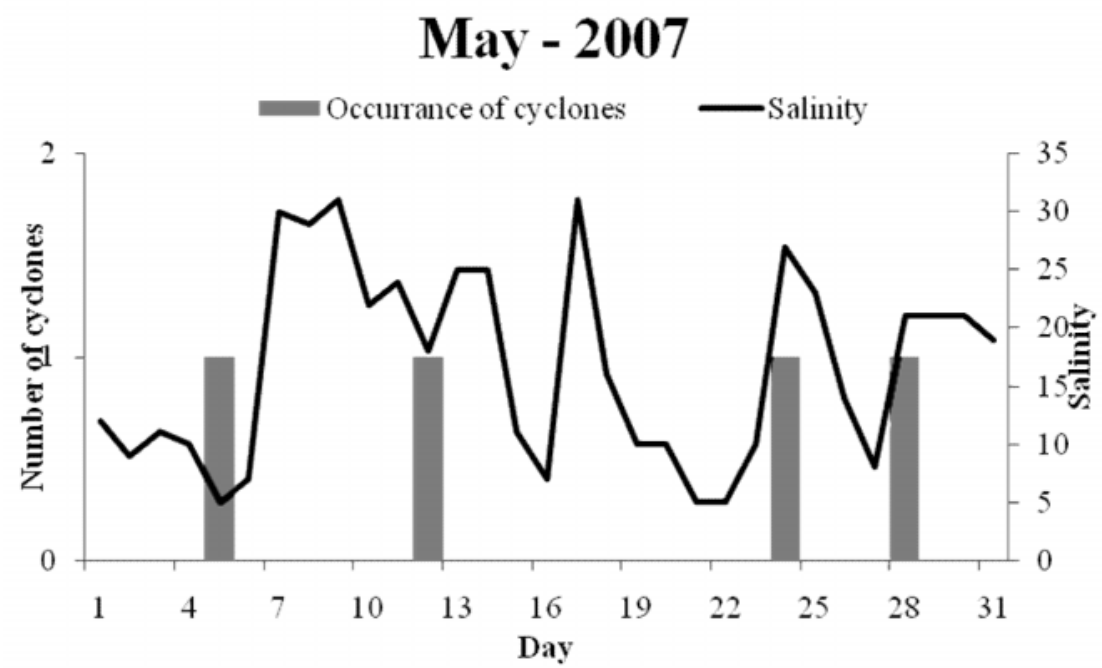

FIGURE 22 - Relationship between passage of extratropical cyclones and salinity in the estuary of Patos Lagoon in may/2007.

\section{June - 2007}

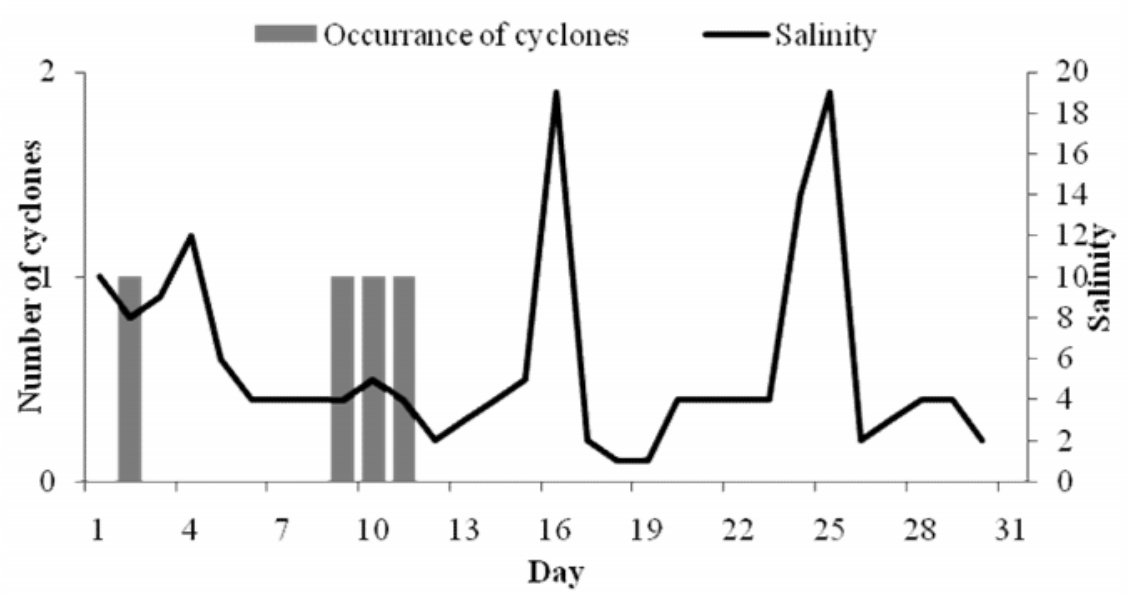

FIGURE 23 - Relationship between passage of extratropical cyclones and salinity in the estuary of Patos Lagoon in june/2007.

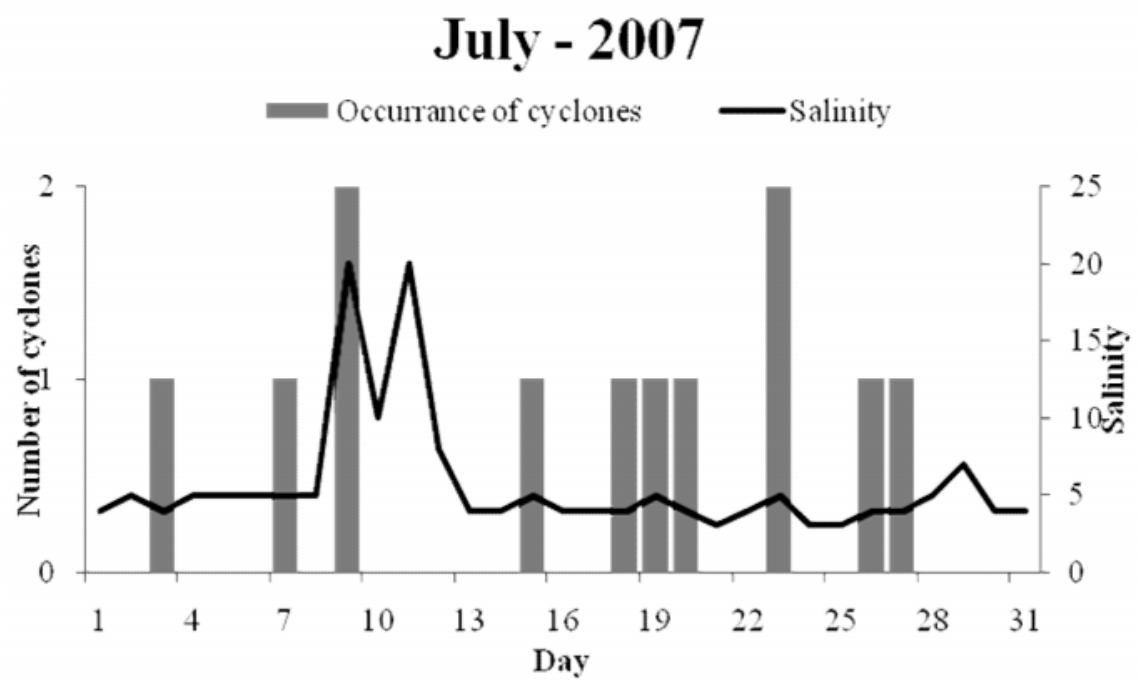

FIGURE 24 - Relationship between passage of extratropical cyclones and salinity in the estuary of Patos Lagoon in july/2007. 


\section{August - 2007}

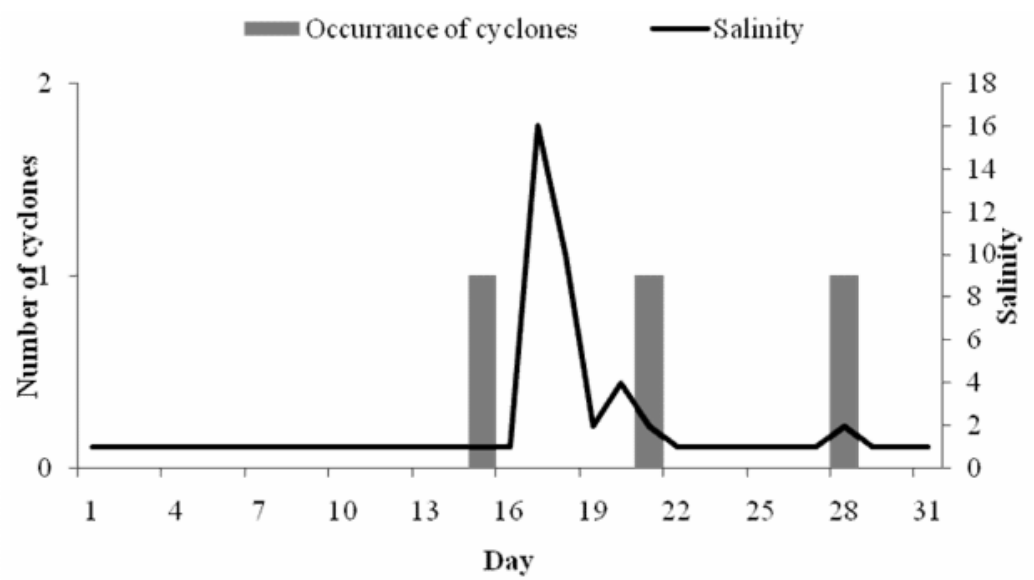

FIGURE 25 - Relationship between passage of extratropical cyclones and salinity in the estuary of Patos Lagoon in august/2007.

\section{September - 2007}

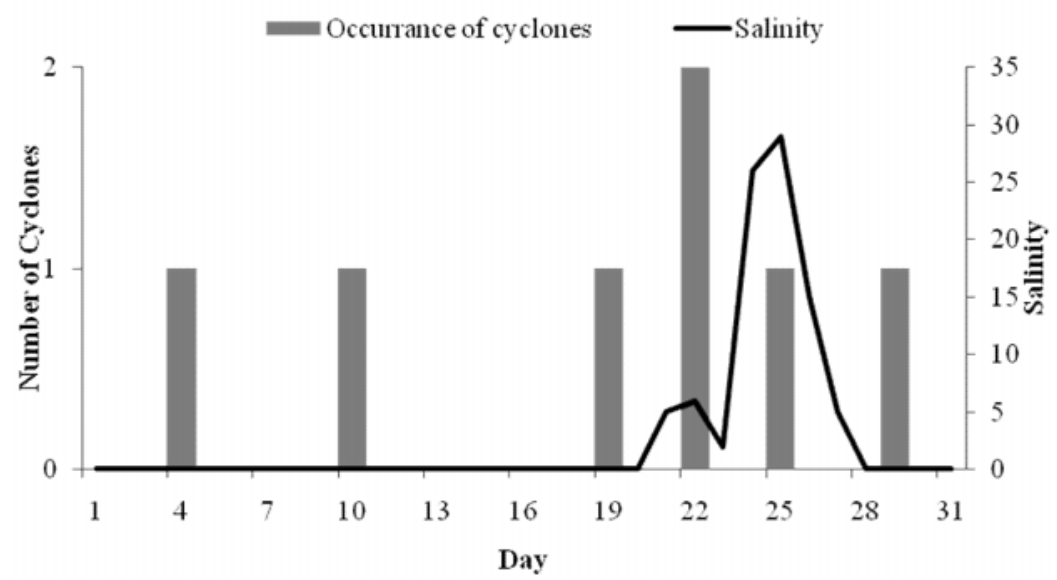

FIGURE 26 - Relationship between passage of extratropical cyclones and salinity in the estuary of Patos Lagoon in september/2007.

\section{October - 2007}

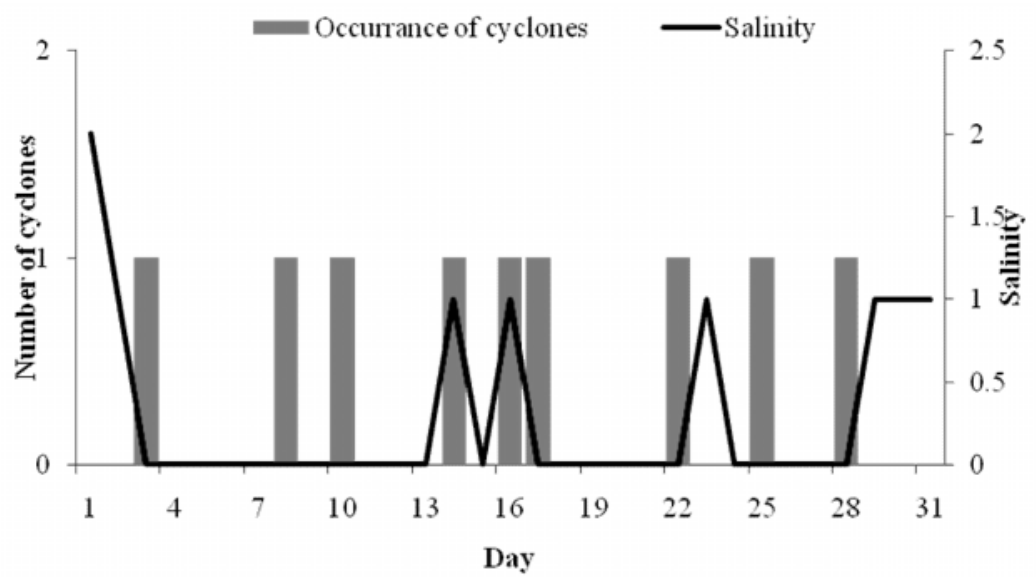

FIGURE 27 - Relationship between passage of extratropical cyclones and salinity in the estuary of Patos Lagoon in october/2007. 


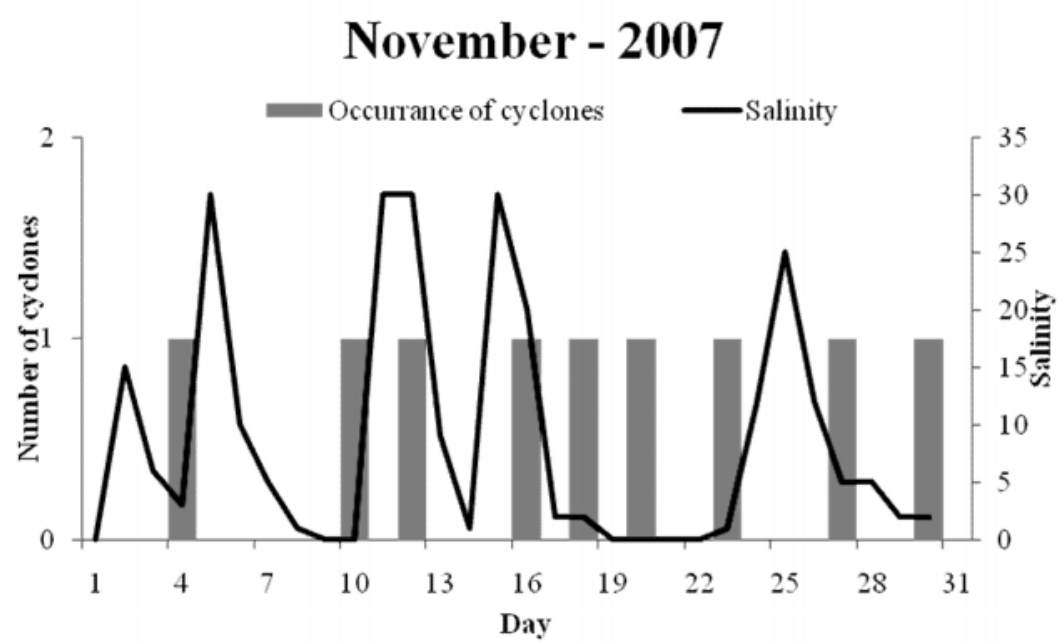

FIGURE 28 - Relationship between passage of extratropical cyclones and salinity in the estuary of Patos Lagoon in november/2007.

\section{December - 2007}

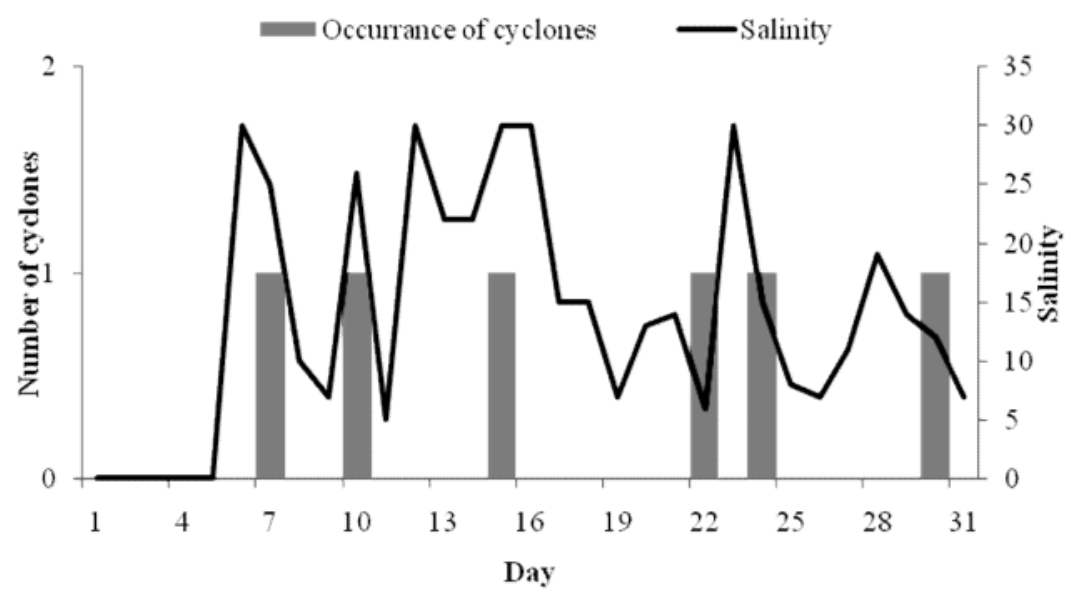

FIGURE 29 - Relationship between passage of extratropical cyclones and salinity in the estuary of Patos Lagoon in december/2007.

\section{January - 2008}

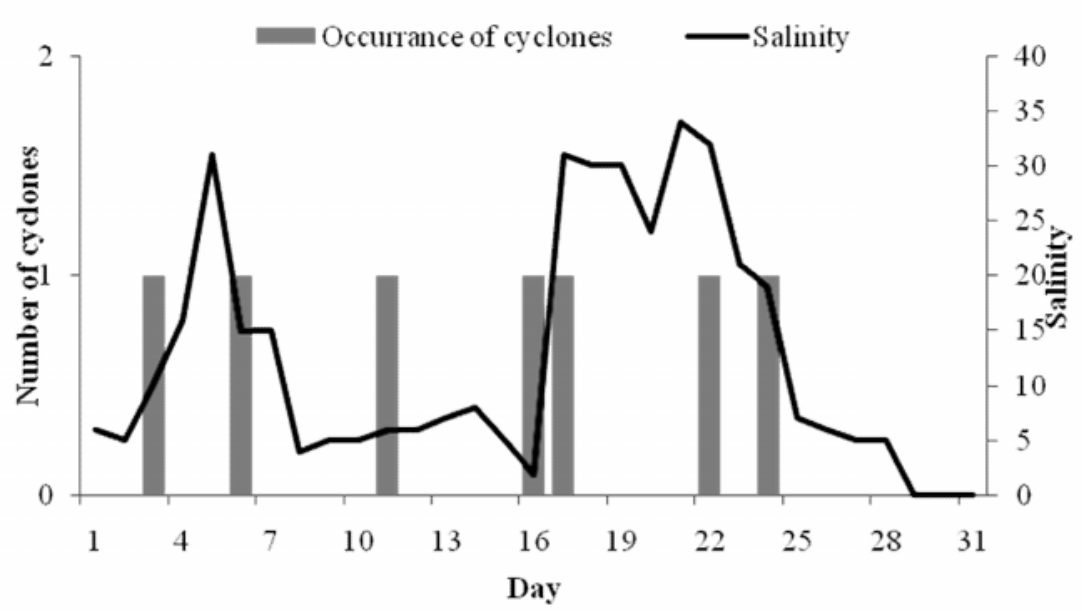

FIGURE 30 - Relationship between passage of extratropical cyclones and salinity in the estuary of Patos Lagoon in january/2008. 


\section{February - 2008}

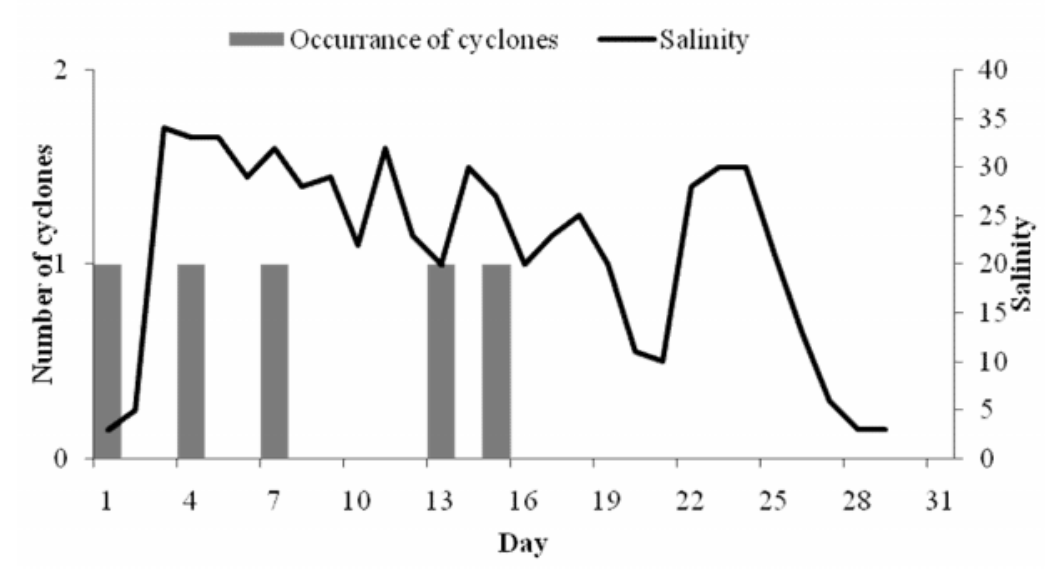

FIGURE 31 - Relationship between passage of extratropical cyclones and salinity in the estuary of Patos Lagoon in february/2008.

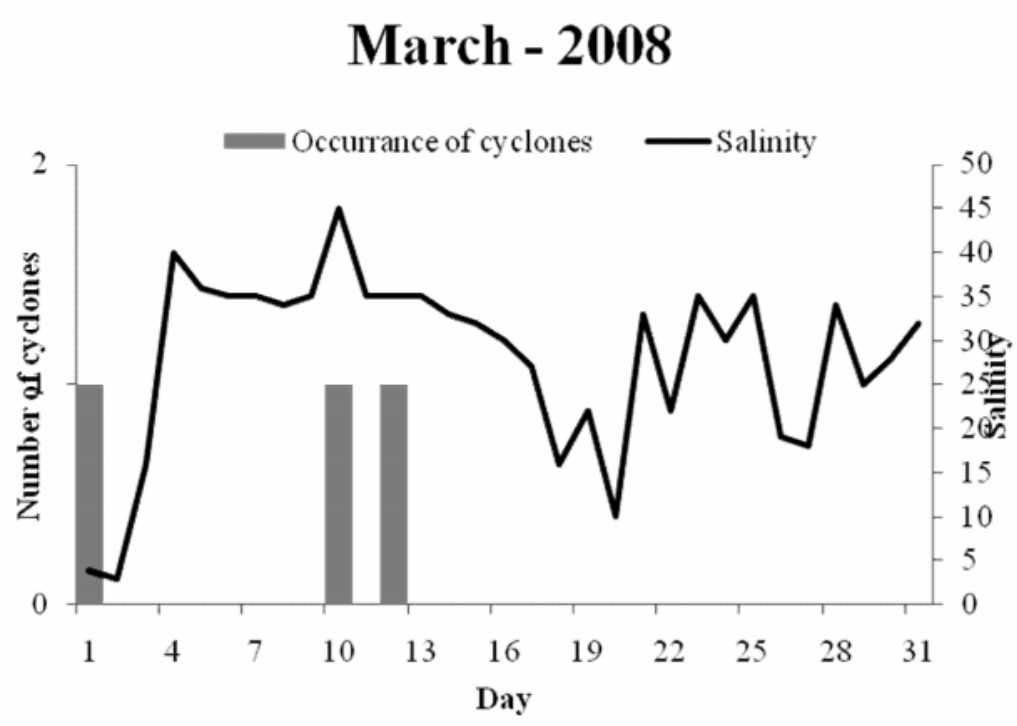

FIGURE 32 - Relationship between passage of extratropical cyclones and salinity in the estuary of Patos Lagoon in march/2008.

The incidence of EC for both periods was higher in winter than in summer, in agreement with the seasonal variation of cyclones described by Taljard (1967,) Necco (1982), Gan \& Rao (1991) e Simmonds \& Keay $(2000 a, b)$ and in contradiction to Satyamurty et al (1990) because he relied his studies on satellite images, and thus may have included cyclogenesis in high levels damaging statistics. The month of July is emphasized as the one with the higher occurrence of CE.

In the months corresponding to El Niño occurred 55 extratropical cyclones with internal pressure lower than $1010 \mathrm{hPa}$, which $79 \%$ of them contributed to the increase of salinity in the estuary of
Patos Lagoon (Table 1). With the movement of these systems the South Wind begins to dominate, allowing the input of seawater into the estuary. It was also observed that during this period the EC were closer to the coast of South America.

During El Niño, the EC moved more slowly (Table 1), taking an average of 3.8 days to dissipate while during La Niña, took 2.4 days. This allows determining that the number of hours of South Wind was higher during El Niño, enabling a larger input of brackish water in the estuary.

Previous studies indicate that during La Niña might occur decrease in rates of pluvial precipitation in southern Brazil, promoting a lower discharge of Patos Lagoon (Garcia 1998, Fernandes et al 2002 and 
Marques 2009; therefore, it was expected a higher influence of EC on the salinity increasing in this area. However, there was a lower ratio when compared to El Niño. In addition, it was possible to observe that during La Niña the EC occurred in a region further away from coast of Rio Grande do Sul, not contributing to the supply of seawater into the estuary.

During La Niña there was a higher relation between the passage of cyclones and increasing salinity in the estuary in the summer months. Usually for the phenomenon, the average annual rainfall is smaller, because there is intensifying of the frontal systems that pass through the region.

Solman and Menéndez (2002) investigated the interanual variability of the EC in the Southern Hemisphere winter and found that the baroclinic instability of the mean flow is higher in El Niño events. Although there is an increase in baroclinic in El Niño years, there is also the reduction of turbulent activity at high levels since there is no time enough for the energy be radiated into the upper troposphere and thus the vertical transport of energy is less efficient than La Niña.

Analyzing all significant increases in salinity that occurred in the estuary, $80 \%$ of them occurred after the passage of an EC for the study region.

\section{ACKNOWLEDGEMENTS}

To CNPq (National Research Council), that funded this work through master's and undergraduated scholarships research.

\section{REFERENCES}

ASMUS, ML. 1997. Coastal Plain and Patos Lagoon. Subtropical Convergence Environments - The Coast and Sea in the Southwestern Atlantic. U. Seeliger, C.Odebrecht, and J. P. Castello, Springer Verlag, 1: 9-12.

CALLIARI, LJ; HAM TOZZI \& AHF KLEIN. 1998. Beach morphology and coastline erosion associated with storm surge in southern Brazil- Rio Grande to Chuí, RS. An. Acad. Bras. Cienc, 70: 231 247.

CASTELLO, JP. 1985. La Ecologia de Los Consumidores Del Estuario de Lagoa dos Patos, Brasil. Fish Community Ecology in Estuaries And Coastal Lagoons: Towards An Ecosystem Integration Ed. A.Yanez-Arancibia. Universidade Nac Aut Mex Chap, México, 17: 383-406.
COSTA, CSB; U SEELIGER \& PG KINAS. 1988. The effect of wind velocity and direction on the salinity regime in the Patos Lagoon estuary. Ciência Cult, 40: 909-912.

D'INCAO, F. 1991. Pesca e biologia de Penaeus paulensis na Lagoa dos Patos, RS. Atlântica, 13: 159-169.

FERNANDES, EHL; KR DYER; OO MÖLLER \& LFH NIENCHESKI. 2002. The Patos Lagoon hydrodynamics during El Niño event (1998). Continental Shelf Research, 22: 1699-1713.

GAN, MA. \& BV RAO. 1991. Surface ciclogenesis over South America. Mon. Wea. Rev, 119: 293-302.

GARCIA, CAE. 1998. Características Hidrográficas. Os ecossistemas costeiros e marinhos do extremo sul do Brasil. Rio Grande. Seeliger, U., Odebrecht, C. and Castello, J.P. Ed. Ecoscientia, 1: 18-21.

KJERFVE, B. 1986. Comparative oceanography of coastal lagoons. Estuarine variability. Ed. D. A. Wolfe. Academic Press, New York, 63-81

LEMOS, CF \& NO Calbete. 1996. Sistemas Frontais que Atuaram no Brasil de 1987 a 1995. Climanálise, Ed. Especial Comemorativa 10 anos- MCT/INPE/CPTEC.

MARQUES, WC. 2009. Estudo da dinâmica da pluma costeira da Lagoa dos Patos. Tese de Doutorado. Universidade Federal do Rio Grande.

SINCLAIR, MR. 1994. A contribution to the problem of development. Quart. J. Roy. Meteor. Soc, 122: 2239-2256.

NECCO, G. 1982. Comportamiento de vortices ciclonicos en el area Sudamericana durante el FGGE : Ciclogenesis. Meteorologica, 13: 7-19.

PARISE, CK; LJ CALLIARI \& N Krusche. 2009. Extreme storm surges in the south of Brazil: Atmospheric conditions and shore erosion. Braz. Journal of Ocean, 53: 75-188.

PEZZA A. 2003. Ondas de frio na América do sul e as trajetórias dos ciclones e anticiclones extratropicais: climatologia sinótica, dissertação de doutorado, departamento de ciências atmosféricas, instituto de astronomia, geofísica e ciências atmosféricas, São Paulo, junho de 2003.

SATYAMURTY, P; CC FERREIRA \& MA GAN. 1990. Cyclonic Vortices over South America, Tellus, 42(A): 194-201.

SIMMONDS I \& K KEAY. 2000. Variability of Southern Hemisphere extratropical cyclone behaviour 1958-97. Journal of Climate, 13: 550-561.

SIMMONDS, I \& K KEAY. 2000. Mean southern hemisphere extratropical cyclone behavior in the 40-year NCEP-NCAR reanalysis. J. Climate, 13: 873-885.

SOLMAN, AS. \& CG MENÉNDEZ. 2002. ENSO - Related Variability of the Southern Hemisphere Winter Storm Track over the Eastern Pacific-Atlantic Sector. Journal of the Atmospheric Sciences, 59: 2128-2140.

TALJARD, JJ. 1967. Development, distribution and movement of cyclones and anticyclones in the Southern Hemisphere during the IGY. J. appl. Met, 6: 973-987.

VIANELLO, RL \& AR ALVES. 1991. Meteorologia Básica e Aplicações. Universidade Federal de Viçosa. Imprensa Universitária. Viçosa-MG. 449p.

Submetido: 08/09/2011

Aceito: 11/06/2012 
